\title{
Environmental Management System and Organizational Performance in Malaysian Manufacturing Industry
}

\author{
Nursyazwani Mohd Fuzi, Nurul Fadly Habidin, Sabrinah Adam and Sharon \\ Yong Yee Ong
}

To Link this Article: http://dx.doi.org/10.6007/IJARBSS/v11-i3/8978

DOI:10.6007/IJARBSS/v11-i3/8978

Received: 03 February 2021, Revised: 01 March 2021, Accepted: 10 March 2021

Published Online: 17 March 2021

In-Text Citation: (Fuzi et al., 2021)

To Cite this Article: Fuzi, N. M., Habidin, N. F., Adam, S., \& Ong, S. Y. Y. (2021). Environmental Management System and Organizational Performance in Malaysian Manufacturing Industry. International Journal of Academic Research in Business and Social Sciences, 11(3), 664-669.

Copyright: (c) 2021 The Author(s)

Published by Human Resource Management Academic Research Society (www.hrmars.com)

This article is published under the Creative Commons Attribution (CC BY 4.0) license. Anyone may reproduce, distribute, translate and create derivative works of this article (for both commercial and non-commercial purposes), subject to full attribution to the original publication and authors. The full terms of this license may be seen at: http://creativecommons.org/licences/by/4.0/legalcode

Vol. 11, No. 3, 2021, Pg. 664 - 669

Full Terms \& Conditions of access and use can be found at http://hrmars.com/index.php/pages/detail/publication-ethics 


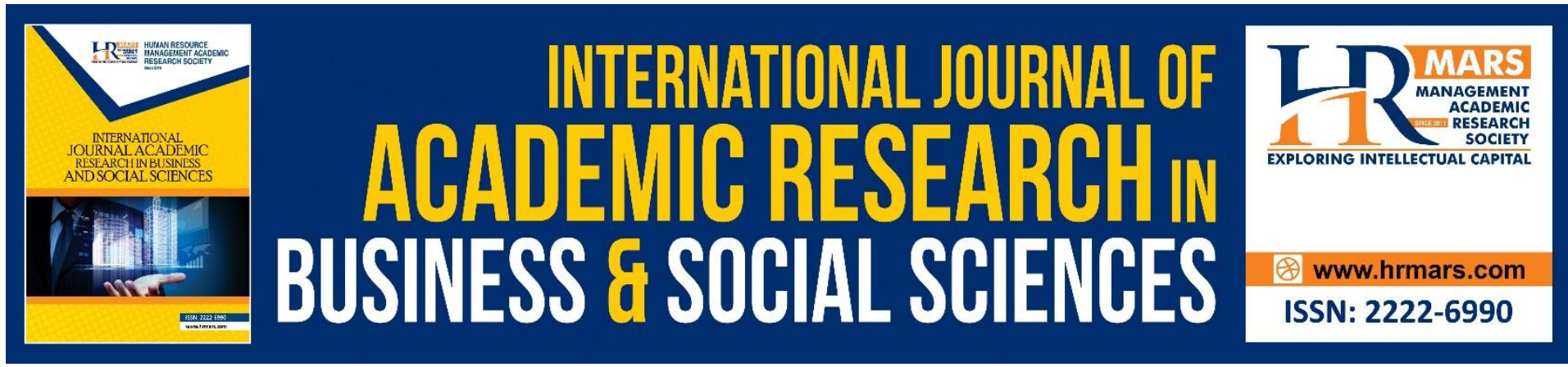

\title{
Environmental Management System and Organizational Performance in Malaysian Manufacturing Industry
}

\author{
Nursyazwani Mohd Fuzi ${ }^{1}$, Nurul Fadly Habidin², Sabrinah \\ Adam $^{3}$, and Sharon Yong Yee Ong ${ }^{4}$ \\ ${ }^{1,3}$ Azman Hashim International Business School, Universiti Teknologi Malaysia, \\ 81310 Johor Bahru, Johor, Malaysia, ${ }^{2}$ Department of Business Management and \\ Entrepreneurship, Faculty of Management and Economics, Universiti Pendidikan Sultan \\ Idris, 35900 Tanjung Malim, Perak, Malaysia, ${ }^{4}$ Department of Social Science, Faculty of \\ Humanities, Management and Science, Universiti Putra Malaysia Campus Bintulu Sarawak, \\ 97008 Bintulu, Sarawak, Malaysia \\ Email: nursyazwani.mohdfuzi@utm.my
}

\begin{abstract}
The aim of this conceptual paper is to review the relationship between environmental management system and organizational performance in Malaysian manufacturing industry. The paper is prepared by reviewing the relevant literatures on environmental management system and organizational performance. The framework will provide a guide to Malaysian manufacturing industry to improve the environmental management system and organizational performance. The conceptual framework developed in this study can be used as a guideline to implement the environmental management system and organizational performance in Malaysian manufacturing industry. Thus, a conceptual framework of the importance of environmental management system and organizational performance, can serve to guide future research.
\end{abstract}

Keywords: Environmental Management System, Organizational Performance, Planning, Auditing, Manufacturing Industry

\section{Introduction}

Management accounting research can assist managers to access the management system and to achieve the company's goals (Robalo, 2014). In this study, Environmental Management System (EMS) plays an important role within organizations by applying useful environmental information. Regarding to this, companies can include EMS as a key element of the management accounting perspective. This is because EMS can be a successful tool within organizations to improve the performance. In addition, EMS is expected to assist organizations in improving environmental management by providing useful information (Ghasemi et al., 2016). Due to this, the implementation of EMS can assist organizations in making more accurate decisions, which will lead to improving the performance. Hence, the 
EMS implementation can assist organizations to make better decisions and improve the performance based on the management accounting perspective.

Management accounting describes the techniques and procedures that provide financial and non-financial information to make better decisions in order to improve OPM and to achieve the organizational objectives (Kihn, 2010). The use of management accounting can improve the performance measurements. In this regard, performance measurement has been the dependent variable of management accounting research (Noordin et al., 2015; Fuzi et al., 2016).

EMS plays an important role in providing environmental information and improving OPM (Islam \& Hu, 2012; Fuzi, Habidin et al., 2019). These findings also showed that the contingency theory includes complying with environmental regulations, improving environmental management, reducing environmental risks, and enhancing environmental audits. Joshi and Li (2016) also discussed the connection between EMS and OPM. In this regard, the contingency theory can be considered as evidence for improving EMS and OPM, thus providing support for the contingency theory. Therefore, this study concludes that the contingency theory is one of the instruments to improve management systems and the practices of an organization, particularly in the Malaysian manufacturing industry. From the above discussion, it is clear that the contingency theory is important in influencing the environmental information of organizations in the Malaysian manufacturing industry.

This paper is organized as follows. The literature review is presented in EMS and OPM while the proposed conceptual framework is described in methodology. Finally, the conclusions based on this study.

\section{Literature Review \\ Environmental Management System (EMS)}

Salvado, Castro, and Lopez (2015) mentioned that EMS can assist organizations in addressing environmental issues and that it is intended to reduce costs, and improve the environmental management, performance, and reputation of the company. Moreover, EMS can be used in relation to the performance and continuous improvement of the company. Hariz and Bahmed (2013) stated that EMS refers to the principle of continuous improvement of OPM related to the activities of the company. Thus, EMS is beneficial to the process, procedure, structure, and improvement, especially in Malaysian manufacturing industry.

Singh, Jain, and Sharma (2016) noted that EMS refers to the systematic procedures intended to ensure continuous improvement in improving the performance. In addition, EMS is a management method to manage the environment and to achieve the goal of improving the OPM of the company. In conclusion, the importance of EMS can thus assist the organizations to improve the performance in Malaysian manufacturing industry. The organizations should be aware of the environmental issues by applying EMS implementation.

\section{Organizational Performance (OPM)}

Organizational performance (OPM) refers to the results of an organization as measured to achieve the organizational goals (McGivern \& Tvorik, 1997). The Malaysian manufacturing industry can measure the OPM based on the financial and operational performance. Financial performance measures the company's strategy, evaluation, and outcomes that contribute to OPM (Santis, Albuquerque, \& Lizarelli, 2016; Fuzi, Habidin, Janudin, \& Ong, 2017) such as profitability, sales growth, reduced costs, and return on investment. 
The implementation of operational performance can improve the company's operations and provide the main interest in achieving the organizational goals (lyer, 2011; Fuzi, Habidin, Janudin, \& Ong, 2019). In addition, operational performance contributes in assisting companies to manage the environmental management efficiently and effectively (Parast, Adams, \& Jones, 2011). Hwang, Han, Jun, and Park (2014) pointed out that operational performance is used to measure the operational effectiveness.

\section{Research Methodology}

In this study, the conceptual framework is developed and tested using structural equation modelling (SEM) based on the previous studies. Structural equation modelling is used to examine the relationship of environmental management system and organizational performance. The main constructs are proposed in order to develop the proposed conceptual framework. This framework can be used as a guideline to improve environmental management system and organizational performance. The questionnaires were distributed to the respondents using an online survey tool followed by telephone calls and through mail. The survey will conduct in two stages, the pilot study and the main study. The pilot study is carried out prior to the main study to ensure the validity and the reliability of the instrument.

\section{A Proposed Conceptual Framework}

The proposed conceptual framework aims to examine the relationship between EMS and OPM in Malaysian manufacturing industry. Figure 1.1 represents the proposed conceptual framework by the researcher.

$\mathbf{H}_{1}$ : There is a positive and significant relationship between EMS and OPM in Malaysian manufacturing industry.

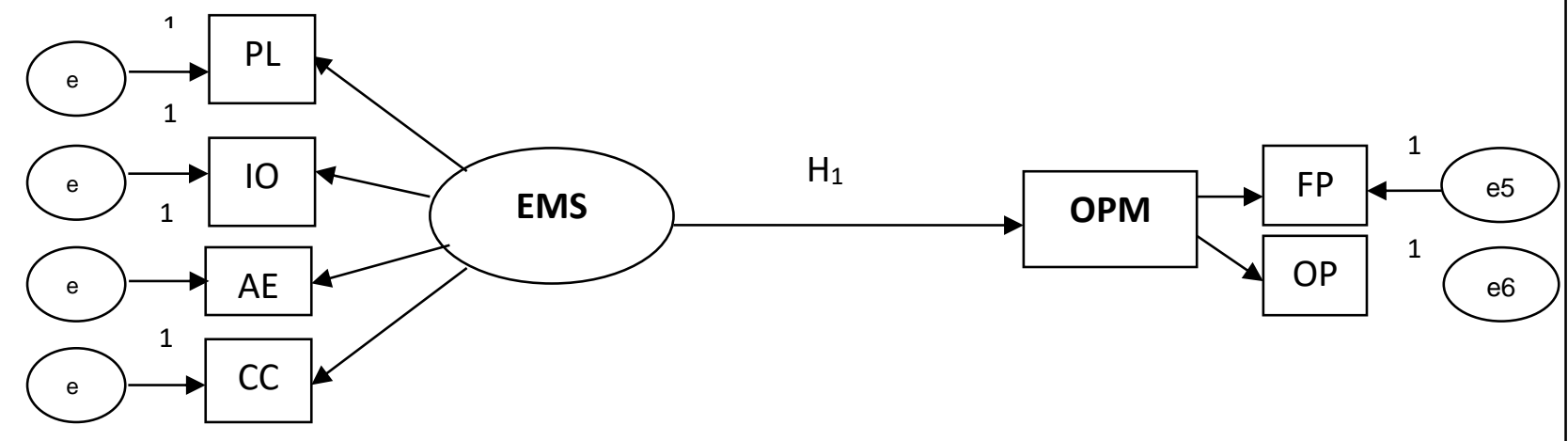

*Notes: EMS=Environmental Management System, OPM=Organizational Performance, $\mathrm{PL}=$ Planning, $\mathrm{IO}=\mathrm{Implementation}$ and Operation, $\mathrm{AE}=$ Auditing and Evaluation, $\mathrm{CC}=\mathrm{Checking}$ and Correction Action, $\mathrm{FP}=$ Financial Performance, $\mathrm{OP}=$ Operational Performance

Figure 1. The Proposed Conceptual Framework 
Farok and Searcy (2015) conducted a research in China to examine the relationship between EMS and OPM. The result of the study found that EMS implementation was positively and significantly related to OPM. OPM can be improved by implementing EMS in the organization. Research was conducted by Phan and Baird (2015) to investigate the relationship between EMS and OPM in Australian organizations by engaging 820 managers from agriculture, mining, manufacturing, construction, and health sectors. Results indicated that there was a link between EMS and OPM. Another research conducted in the Swedish manufacturing industry, and results showed that there was a positive relationship between EMS and OPM (Zobel \& Malmgre, 2016). As a result, it was strengthening the effect of EMS on OPM can improve the environmental management in Malaysian manufacturing industry.

\section{Conclusion}

In conclusion, EMS has the potential to improve OPM in Malaysian manufacturing industry. It is a reasonable expectation to implement EMS in Malaysian manufacturing industry, hence resulting in better OPM. For practical implications, this research provides important guidelines for manufacturers and related companies to implement EMS in order to improve OPM. This research provides important information for decision makers involved in EMS implementation and also provides useful references for future researchers in this research area. This result could be used as a specific reference for policy making to continuously improve the OPM. These findings suggest that policy makers and government need specifically emphasize the implementation of EMS and OPM to encourage the integration of environmental issues into decision-making. Future research in the area EMS and OPM can be extended in a number of directions. Apart from these contributions, the research outcome has also provided useful guidance for future research. Therefore, it can be concluded that the implementation of EMS is found to be useful to Malaysian manufacturing industry and is considered successful in enhancing the OPM.

\section{Acknowledgement}

The researchers would like to acknowledge the Research Management Centre (RMC), Universiti Teknologi Malaysia.

\section{References}

Fuzi, N. M., Habidin, N. F., Janudin, S. E., \& Ong, S. Y. Y. (2019). Environmental management accounting practices, management system, and performance: SEM approach. International Journal of Quality \& Reliability Management, 37(9/10), 1165-1182.

Fuzi, N. M., Habidin, N. F., Janudin, S. E., \& Ong, S. Y. Y. (2017). The relationship between environmental information system and performance for Malaysian manufacturing industry. International Journal of Academic Research in Business and Social Sciences, 7(12), 346-350.

Fuzi, N. M., Habidin, N. F., Janudin, S. E., \& Ong, S. Y. Y. (2016). Environmental management accounting practices and environmental performance for Malaysian manufacturing industry. International Journal of Academic Research in Business and Social Sciences, 6(11), 135-141.

Fuzi, N. M., Habidin, N. F., Janudin, S. E., Ong, S. Y. Y., \& Bahador, K. M. K. (2019). Environmental management accounting practices and organizational performance: The mediating effect of information system. Measuring Business Excellence, 23(4), 411-425. 
Ghasemi, R., Mohamad, N. A., Karami, M., Bajuri, N. H., \& Asgharizade, E. (2016). The mediating effect of management accounting system on the relationship between competition and managerial performance. International Journal of Accounting and Information Management, 24(3), 272-295.

Hariz, S., \& Bahmed, L. (2013). Assessment of environmental management system performance in the Algerian companies certified ISO 14001. Management of Environmental Quality: An International Journal, 24(2), 228-243.

Islam, J., \& Hu, H. (2012). A review of literature on contingency theory in managerial accounting. African Journal of Business Management, 6(15), 5159-5164.

Iyer, K. N. S. (2011). Demand chain collaboration and operational performance: Role of IT analytic capability and environmental uncertainty. Journal of Business \& Industrial Marketing, 26(2), 81-91.

Joshi, S., \& Li, Y. (2016). What is corporate sustainability and how do firms practice it? A management accounting research perspective. Journal of Management Accounting Research, 28(2), 1-11.

Kihn, L. (2010). Performance outcomes in empirical management accounting research: Recent developments and implications for future research. International Journal of Productivity and Performance Management, 59(5), 468-492.

McGivern, M. H., \& Tvorik, S. J. (1997). Determinants of organizational performance. Management Decision, 35(6), 417-435.

Noordin, R., Zainuddin, Y., Fuad, A., Mail, R., \& Sariman, N. K. (2015). Performance outcomes of strategic management accounting information usage in Malaysia: Insights from electrical and electronics companies. Procedia Economics and Finance, 31, 13-25.

Parast, M. M., Adams, S. G., \& Jones, E. C. (2011). Improving operational and business performance in the petroleum industry through quality management. International Journal of Quality \& Reliability Management, 28(4), 426-450.

Robalo, R. (2014). Explanations for the gap between management accounting rules androutines: An institutional approach. Spanish Accounting Review, 17(1), 88-97.

Salvado, J. A., Castro, G. M., \& Lopez, J. E. N. (2015). The importance of the complementarity between environmental management systems and environmental innovation capabilities: A firm level approach to environmental and performance benefits. Technological Forecasting \& Social Change, 96(7), 288-297.

Santis, P., Albuquerque, A., \& Lizarelli, F. (2016). Do sustainable companies have a better financial performance? A study on Brazilian public companies. Journal of Cleaner Production, 133(10), 735-745.

Singh, N., Jain, S., \& Sharma, P. (2016). Environmental benchmarking practices in Indian industries. Benchmarking: An International Journal, 23(5), 1132-1146. 